\title{
Effects of false yam tuber meals and charcoal on broiler chicken production and blood parameters
}

\author{
R. Roessler ${ }^{1 \#}$, L. Amprako², A.R. Sayibu ${ }^{3}$, A. Mohammed ${ }^{3}$, R.C. Menezes ${ }^{4}$, D. \\ Hölscher $^{2,5}$, B. Alenyorege ${ }^{3}$, H.K. Dei ${ }^{3}$ \& C. Steiner ${ }^{2}$ \\ ${ }^{1}$ University of Kassel and Georg-August-Universität Göttingen, Animal Husbandry in the Tropics and Subtropics, \\ Steinstr. 19, 37213 Witzenhausen, Germany \\ ${ }^{2}$ University of Kassel, Organic Plant Production and Agroecosystems Research in the Tropics and Subtropics, Steinstr. \\ 19, 37213 Witzenhausen, Germany \\ ${ }^{3}$ University for Development Studies (UDS), Department of Animal Science, Faculty of Agriculture, P.O. Box TL 1882, \\ Tamale, Ghana \\ ${ }^{4}$ Max Planck Institute for Chemical Ecology, Research Group Mass Spectrometry, Hans-KnöIl-Str. 8, 07745 Jena, \\ Germany \\ ${ }^{5}$ Max Planck Institute for Chemical Ecology, Research Group Biosynthesis/NMR, Hans-Knöll-Str. 8, 07745 Jena, \\ Germany
}

(Received 20 June 2017; Accepted 30 August 2017; First published online 4 October 2017)

Copyright resides with the authors in terms of the Creative Commons Attribution 4.0 South African License. See: http://creativecommons.org/licenses/by/4.0/za

Condition of use: The user may copy, distribute, transmit and adapt the work, but must recognize the authors and the South African Journal of Animal Science.

\begin{abstract}
The authors investigated the effects of replacing a portion of a commercial broiler feed with false yam tuber meals on broiler growth performance, feed conversion rate (FCR) and blood parameters. Furthermore, wood charcoal was added at various levels to the meals to explore their potential to attenuate toxic effects. One hundred and sixty-eight 28-day-old healthy female broiler chickens (average initial bodyweight $1081.1 \pm$ $66.20 \mathrm{~g}$ ) were randomly assigned to 28 experimental groups (7 dietary treatments, 4 replicates) of six birds each, using a randomized complete block design. Dietary treatments included the control diet (commercial broiler feed) (C), raw false yam tuber meal (RFY) replacing $50 \mathrm{~g} / \mathrm{kg}$ of the commercial broiler feed, false yam tuber meal soaked in water (SFY) replacing $150 \mathrm{~g} / \mathrm{kg}$ of the commercial broiler feed, RFY with $30 \mathrm{~g} / \mathrm{kg}$ and $60 \mathrm{~g} / \mathrm{kg}$ wood charcoal, and SFY with $30 \mathrm{~g} / \mathrm{kg}$ and $60 \mathrm{~g} / \mathrm{kg}$ wood charcoal. Growth performance, feed intake and FCR were assessed over four weeks. At the end of the experiment, blood samples were collected from 21 birds (three from each dietary treatment) to analyse haematological and serum biochemical parameters. Analysis of variance, Kruskal-Wallis tests, and simple regressions were used to evaluate the effects of the meals and charcoal. The results indicated that broilers fed $150 \mathrm{~g} / \mathrm{kg} \mathrm{SFY}$ had a significantly lower growth rate and poorest FCR. Consequently, highest bodyweights were observed for C and RFY diets. Additionally, blood serum proteins were below the references ranges for birds fed SFY, particularly with additional charcoal. In contrast, RFY could be included at $50 \mathrm{~g} / \mathrm{kg}$ in broiler chicken diets without any adverse effects on their performance and blood (serum) parameters. Anti-nutritional substances contained in SFY at this substitution level are harmful to the birds, irrespective of whether charcoal is added or not. In contrast, RFY could replace commercial feed at the studied level $(50 \mathrm{~g} / \mathrm{kg})$.
\end{abstract}

Keywords: Feed efficiency, growth performance, haematology, serum biochemistry, terpenes

\#Corresponding author: regina.roessler@uni-kassel.de

\section{Introduction}

False yam (Icacina oliviformis (Poiret) J. Raynal, synonym I. senegalensis A. Juss, family Icacinaceae) is a drought-resistant shrub that is native to West and Central Africa (NRC, 2008). It belongs to the family of Icacinaceae, the phylogenetic relationships of which are still under discussion (Byng et al., 2014). It provides three edible products that are appreciated for human consumption, namely fruits, seeds, and large starchrich tubers (NRC, 2008). Sun-dried false yam tuber meals contain $486.3 \mathrm{~g} / \mathrm{kg}$ starch, high levels of neutral detergent fibre (286.1 g/kg dry matter (DM)), but low levels of crude protein (CP) (54.1 g/kg DM) (Dei et al., 
2011). Umoh \& Iwe (2014) reported that false yam is a good source of the micronutrients that are necessary for human nutrition such as potassium, sodium, calcium and zinc. Recently, extensive research has focused on the phytochemical profile of Icacina trichantha Oliv. It revealed pimarane-type diterpenoid compounds belonging to the small subclasses of 17-norpimarane, $(9 \beta \mathrm{H})$-pimarane, $(9 \beta \mathrm{H})$-17-norpimarane, 16,17-di-norand 17,19-di-nor-pimarane, a rare compound class in nature (Onakpa et al., 2014; Zhao et al., 2015; Guo et al., 2016). Pimarane-type momilactones are also found in rice plants (Oryza sativa) and mosses (Hypnum plumaeforme and Pseudoleskeella papillosa). These secondary metabolites are known for their cytotoxic and antitumor activities (Onakpa et al., 2014; Kim et al., 2007) and are reported to function as phytoalexins and allelochemicals (Nozaki et al., 2007; Liu et al., 2012; Kato-Noguchi \& Peters, 2013). Hence several Icacina species are used in popular herbal medicine to treat food poisoning, constipation and malaria and as a starch source during famine for the people of tropical West Africa (Asuzu et al., 1999; Sarr et al., 2011).

Seeds, leaves and tubers of false yam have been described as low-cost alternative feeds for poultry and rabbit production in Ghana (Ansah et al., 2012; Dei et al., 2015a; Alhassan, 2015). However, despite the false yam's abundance in the northern part of the country, its use as alternative poultry feed has been limited. This is probably due to anti-nutritional factors in raw false yam meals (Dei et al., 2011), which affect final bodyweights and carcass characteristics of broiler chickens negatively (Teye et al., 2011).

Traditional food processing methods such as soaking have been suggested to wash toxic substances out of false yam tubers. For instance, Dei et al. (2015a) and Dei et al. (2015b) proved that broiler chickens fed tubers that were soaked in water or a saltpetre solution had similar performances to broiler chickens fed a normal diet. Adding dietary wood charcoal to false yam meals might further reduce the negative effects of toxic substances (Gerlach \& Schmidt, 2012). Although charcoal as a general feed additive has received a great deal of interest in recent years, scientific studies that address this topic in broiler chickens are scarce (Kutlu et al., 2001, Kana et al., 2011). The objectives of the present experiment were therefore i) to compare growth performance, feed intake and feed conversion rate, ii) to compare haematological and serological profiles of female broiler chickens fed raw and soaked false yam tuber meals, and iii) to evaluate whether wood charcoal could attenuate the toxic effects of the two false yam tuber meals.

\section{Materials and methods}

The study was conducted in February/March 2016 at the University for Development Studies (UDS), Tamale, northern Ghana. The outdoor temperature during the experiment averaged $32.1 \pm 1.4{ }^{\circ} \mathrm{C}$, with a minimum of $28.8{ }^{\circ} \mathrm{C}$ and maximum of $34.8^{\circ} \mathrm{C}$. The average relative humidity was $31.0 \pm 18.1 \%$, ranging between $7.3 \%$ and $69.1 \%$. The poultry house was open sided to allow for natural ventilation. Light was provided $24 \mathrm{~h} \mathrm{~d}^{-1}$, as is common practice in northern Ghana to stimulate feed intake during cooler night temperatures (Dei et al., 2011). The intensity of light was $10 \mathrm{~lx}$. Ethical clearance was obtained on 14 January 2016 from UDS (code number ANS/FOA/02/14012016). The experiment was conducted in compliance with regulations for animal experiments of UDS, and was closely supervised by a veterinarian.

At 28 days of age, 168 healthy female broiler chickens (Cobb 500 strain) were selected on a weight equalization basis and randomly assigned to 28 experimental groups with six birds each, using a randomized complete block design. Two blocks consisted of 14 floor pens with deep litter $\left(1.65 \times 0.84 \mathrm{~m}^{2}\right)$ and the other two blocks of 14 pens with wire mesh floor $\left(1.8 \times 0.9 \mathrm{~m}^{2}\right)$. Each dietary treatment was replicated four times. The seven dietary treatments included i) C: commercial broiler finisher diet (control); ii) RFY-0: raw false yam tuber meal, replacing $50 \mathrm{~g} / \mathrm{kg}$ of the commercial broiler feed; iii) SFY-0: false yam tuber meal soaked in water, replacing $150 \mathrm{~g} / \mathrm{kg}$ of the commercial broiler feed; iv) RFY-30: RFY with $30 \mathrm{~g} / \mathrm{kg}$ wood charcoal (WC); v) SFY-30: SFY with $30 \mathrm{~g} / \mathrm{kg} \mathrm{WC}$; vi) RFY-60: RFY with $60 \mathrm{~g} / \mathrm{kg} \mathrm{WC}$; and vii) SFY-60: SFY with $60 \mathrm{~g} / \mathrm{kg}$ WC. The birds were adapted to the diets for one week. Feed and water were provided ad libitum.

All dietary treatments were based on a commercial finisher feed with added vitamin premix and phytase. It was purchased from Agricare Ltd., Kumasi, Ghana, and contained 11.7 MJ metabolizable energy $/ \mathrm{kg}$ according to the manufacturers' declaration. False yam tubers were harvested at UDS Nyankpala campus. They were washed with water, peeled and sliced into chips. A portion of the chips was sun-dried and milled into gritty flour. The other portion was soaked in water (1 part fresh false yam tuber chips to 2 parts water) for 12 days. Water was changed every three days. Finally, the soaked false yam tuber chips were washed, sun-dried and milled into gritty flour. The WC was purchased from Tamale wood and charcoal market, crushed and milled into gritty powder to pass a 1-mm sieve and included in the false yam diets.

Representative samples of each dietary treatment and the pure WC and false yam tuber meals were collected, weighed using an electronic precision balance (3,500 g weighing capacity, $0.01 \mathrm{~g}$ resolution; Kern PCB, Kern und Sohn GmbH, Balingen, Germany), and dried in a hot-air drying oven $\left(80^{\circ} \mathrm{C}\right)$ to constant weight, weighed again, and ground to pass a 1-mm sieve (Cyclotec, FOSS, Hamburg, Germany) before analysis. Following the standard procedures of the Association of German Agricultural Analytic and Research Institutes (VDLUFA, 2006), the DM and organic matter (OM) concentrations of the feedstuffs were 
determined in two replicates per sample by consecutively drying the materials at $105^{\circ} \mathrm{C}$ overnight, weighing the residual, and incinerating it at $550^{\circ} \mathrm{C}$ for 3 hours. The OM concentration was calculated based on the resulting ash weight. A semi-automated Ankom 220 Fibre Analyser (ANKOM Technology, Macedon, NY, USA) served to determine, in two independent steps, the concentrations of ash-free neutral detergent fibre (NDF) and acid detergent fibre (ADFom). Although heat-stable amylase was used for NDF determination (aNDFom), decalin and sodium sulphite were not added to the detergent solutions (Van Soest et al., 1991).

Dumas combustion was used to analyse the samples for their carbon (C) and nitrogen (N) concentration (C/N-TCD analyser, Elementar Analysensysteme $\mathrm{GmbH}$, Hanau, Germany). The N was multiplied by factor 6.25 to obtain the concentration of CP. Phosphorus (P) content in samples was determined by the Vanadate Molybdate method (Hitachi U-2000 photometer, Hitachi Co. Ltd., Tokyo, Japan) (Table 1).

Table 1 Analysed chemical composition of the commercial finisher feed and the two false yam tuber meals with varying levels of wood charcoal used in the broiler chicken experiment $(\mathrm{g} / \mathrm{kg} \mathrm{DM})$

\begin{tabular}{lcccccc}
\hline \multirow{2}{*}{ Item } & \multicolumn{7}{c}{ Composition (g/kg DM) } \\
\cline { 2 - 7 } & OM & aNDFom & ADFom & CP & C & P \\
\hline WC & 875 & nd & nd & 43 & 726 & 1.6 \\
RFY & 973 & 191 & 102 & 36 & 432 & 0.4 \\
SFY & 974 & 210 & 134 & 35 & 431 & 0.5 \\
C & 898 & 163 & 65 & 201 & 416 & 8.1 \\
RFY-0 & 902 & 167 & 80 & 197 & 414 & 8.0 \\
SFY-0 & 917 & 168 & 76 & 171 & 423 & 7.4 \\
RFY-30 & 908 & 167 & 88 & 190 & 430 & 7.6 \\
SFY-30 & 918 & 177 & 90 & 172 & 439 & 7.0 \\
RFY-60 & 912 & 195 & 100 & 176 & 437 & 7.4 \\
SFY-60 & 917 & 211 & 111 & 168 & 441 & 6.7 \\
\end{tabular}

WC: wood charcoal; RFY: pure raw false yam tuber meal; SFY: pure soaked false yam tuber meal; C: commercial broiler finisher feed (control); RFY-0: RFY without WC; SFY-0: SFY without WC; RFY-30: RFY with $30 \mathrm{~g} / \mathrm{kg} \mathrm{WC;} \mathrm{SFY-}$ 30: SFY with $30 \mathrm{~g} / \mathrm{kg} \mathrm{WC;} \mathrm{RFY-60:} \mathrm{RFY} \mathrm{with} 60 \mathrm{~g} / \mathrm{kg}$ WC; SFY-60: SFY with $60 \mathrm{~g} / \mathrm{kg} \mathrm{WC.} \mathrm{DM:} \mathrm{dry} \mathrm{matter;} \mathrm{OM:} \mathrm{organic}$ matter; aNDF-NDFom: neutral detergent fibre assayed with heat-stable amylase and exclusive of residual ash; ADFADFom: acid detergent fibre exclusive of residual ash; CP: crude protein, calculated as nitrogen $\times 6.25$; C: total carbon, P: phosphorus; nd: not determined

To determine essential amino acids (except tryptophan), ion chromatographic methods were used that conformed with the German Food and Feed Code (\$64 LFGB L 49.07-2). Tryptophan was quantified in accordance with procedures specified by the Association of German Agricultural Analytic and Research Institutes using HPLC methods (VDLUFA, 2006). Amino acid concentrations were determined for dietary treatments without WC (C, RFY-0, and SFY-0) and extrapolated for treatments with WC (RFY-30, RFY-60, SFY-30, and SFY-60) (Table 2).

To determine terpenic constituents, $10 \mathrm{~g}$ each of pure tuber meals RFY and SFY were exhaustively extracted with ethanol three times for 30 minutes in a shaking water bath at $30^{\circ} \mathrm{C}$. The ethanol extract was evaporated $\left(<40{ }^{\circ} \mathrm{C}\right)$ and partitioned between $n$-hexane $\mathrm{H}_{2} \mathrm{O}, \mathrm{CHCl}_{3} \mathrm{H}_{2} \mathrm{O}$, EtOAc $\mathrm{H}_{2} \mathrm{O}$ and $n$-butanol $\mathrm{H}_{2} \mathrm{O}$. The subfractions were evaporated $\left(<40{ }^{\circ} \mathrm{C}\right.$ ) and their amounts for RFY meal were $204.0 \mathrm{mg}$ ( $n$-hexane subfraction), $27.8 \mathrm{mg}\left(\mathrm{CHCl}_{3}\right.$ subfraction), $6.8 \mathrm{mg}$ (EtOAc subfraction), $3.6 \mathrm{mg}$ ( $n$-butanol subfraction), and $6.0 \mathrm{mg}\left(\mathrm{H}_{2} \mathrm{O}\right.$-subfraction. For the SFY meal the amounts were $202.2 \mathrm{mg}$ ( $n$-hexane-subfraction), $21.2 \mathrm{mg}$ $\left(\mathrm{CHCl}_{3}\right.$ subfraction), $6.5 \mathrm{mg}$ (EtOAc subfraction), $1.4 \mathrm{mg}$ ( $n$-butanol subfraction), and $4.5 \mathrm{mg}\left(\mathrm{H}_{2} \mathrm{O}\right.$ subfraction). Ultra-performance liquid chromatography-mass spectrometry (UPLC-MS) analyses of Icacina extracts were performed on a $Q$ Exactive Plus hybrid quadrupole-orbitrap mass spectrometer (Thermo Fisher Scientific, Bremen, Germany) equipped with an Ultimate 3000 series RSLC (Dionex, Sunnyvale, CA, USA) chromatograph. An Acclaim C18 column $(150 \times 2.1 \mathrm{~mm}, 2.2 \mu \mathrm{m}$ particles with $120 \AA$ pore diameter, Dionex, Sunnyvale, CA, USA) with a flow rate of $300 \mu \mathrm{L} \mathrm{min}^{-1}$ in a binary solvent system of water (Solvent $A$ ) and acetonitrile (Solvent B), both containing $0.1 \%(\mathrm{v} / \mathrm{v})$ formic acid, was used to separate the extracts chromatographically. Fifteen $\mu \mathrm{L}$ of each extract, diluted $1: 100$, were loaded onto the column and eluted with 
this gradient: linear increase from $0 \%$ B to $100 \%$ B within 15 minutes $-100 \%$ B constant for 5 minutes equilibration time at $0 \% \mathrm{~B}$ for 5 minutes. The mass spectrometer was operated in positive and negative ionization modes using heated-electrospray ionization (H-ESI) in the mass range of $m / z 100$ to 1,000 using $70,000 \mathrm{~m} / \Delta \mathrm{m}$ resolving power in the Orbitrap mass analyser. $\mathrm{H}$-ESI source parameters were set to $4 \mathrm{kV}$ for spray voltage, $35 \mathrm{~V}$ for transfer capillary voltage at a capillary temperature of $300{ }^{\circ} \mathrm{C}$. Data were evaluated and interpreted using Xcalibur v.3.0.63 software (Thermo Fisher Scientific, Waltham, MA, USA) (Hölscher et al., 2017).

Table 2 Amino acid profile of the commercial finisher feed and the two false yam tuber meals with varying levels of wood charcoal used in the broiler experiment

\begin{tabular}{lrrrrrrr}
\hline \multirow{2}{*}{ Amino acid $^{*}(\mathbf{g} / \mathbf{k g}$ DM) } & \multicolumn{7}{c}{ Dietary treatment } \\
\cline { 2 - 8 } & C & RFY-0 & SFY-0 & RFY-30 & SFY-30 & RFY-60 & SFY-60 \\
\hline Arginine & 12.2 & 12.2 & 10.8 & 11.8 & 10.5 & 11.5 & 10.2 \\
Histidine & 6.1 & 6.1 & 5.8 & 5.9 & 5.6 & 5.7 & 5.5 \\
Isoleucine & 8.6 & 8.2 & 7.5 & 8.0 & 7.3 & 7.7 & 7.1 \\
Leucine & 19.7 & 18.3 & 16.9 & 17.8 & 16.4 & 17.2 & 15.9 \\
Lysine & 12.1 & 12.2 & 11.3 & 11.8 & 11.0 & 11.5 & 10.6 \\
Methionine & 3.9 & 3.7 & 3.4 & 3.6 & 3.3 & 3.5 & 3.2 \\
Phenylalanine & 10.5 & 10.1 & 9.1 & 9.8 & 8.8 & 9.5 & 8.6 \\
Threonine & 7.6 & 7.2 & 6.7 & 7.0 & 6.5 & 6.8 & 6.3 \\
Valine & 10.0 & 9.3 & 8.7 & 9.0 & 8.4 & 8.7 & 8.2 \\
Tryptophan & 1.9 & 1.9 & 1.7 & 1.8 & 1.6 & 1.8 & 1.6 \\
& & & & & & & \\
\hline
\end{tabular}

Calculated for RFY-30, RFY-60, SFY-30 and SFY-60. C: commercial broiler finisher feed (control); RFY-0: raw false yam tuber meal (50 g/kg; RFY) without wood charcoal (WC); SFY-0: false yam tuber meal soaked in water (150 g/kg; SFY) without WC; RFY-30: RFY and $30 \mathrm{~g} / \mathrm{kg}$ WC; SFY-30: SFY and $30 \mathrm{~g} / \mathrm{kg}$ WC; RFY-60: RFY and $60 \mathrm{~g} / \mathrm{kg} \mathrm{WC}$; SFY60: SFY and $60 \mathrm{~g} / \mathrm{kg}$ WC. DM: dry matter

For the evaluation of the UPLC-MS-data, a database was created of 25 reported pimarane-type diterpenoids identified from Icacina species producing such compounds. These secondary metabolites were listed according to their exact mass, with isomers grouped together. The evaluation of subfractions of raw and soaked false yam tuber material revealed the exact mass of all listed isomer groups of pimarane-type candidate structures (Table 3). Because of the lack of reference compounds, differentiation between candidates with an identical molecular formula was not possible. In terms of reported isomers, two (Nos. 4 and 11 in Table 3) have been identified in I. oliviformis (Vanhaelen et al., 1987). The exact mass of $\mathrm{m} / \mathrm{z}$ 391.17622 can be assigned to $[\mathrm{M}+\mathrm{H}]^{+}$of icacinol and the $\mathrm{m} / \mathrm{z} 359.11371$ is attributable to icacenone, two pimarane diterpenoids isolated from $I$. oliviformis. This method provides rapid information about the phytochemical constituents of biological samples.

Broiler chickens were weighed individually each week using an electronic precision balance $(3,500 \mathrm{~g}$ weighing capacity, $0.01 \mathrm{~g}$ resolution; Kern PCB, Kern und Sohn GmbH, Balingen, Germany). The average daily weight gain (ADG) (g/d) was calculated by deducting the individual bird weight at the end of the previous week from the weight at the end of the experimental week, divided by seven days. The average weight was calculated per treatment, corrected for mortalities. Feed intake was assessed weekly for each replicate, and calculated as the difference between the amount of feed offered during the week and feed refused at the end of the week. This was divided by the number of days (7). The average daily feed intake (DFI) was obtained ( $\mathrm{g} / \mathrm{bird}$ and day). The FCR was calculated per replicate as unit of feed consumed daily per unit of $A D G(g / g)$.

At the end of the experimental period (at 63 days of age), one bird from three replicates of each treatment was randomly selected for blood sampling. The selected birds were restrained and $2 \mathrm{~mL}$ of blood were drawn from their wing veins with a syringe and needle. Blood samples for haematological evaluation were collected into EDTA tubes, while blood samples for blood chemistry evaluation were collected without anticoagulant. Samples were kept in cooled condition prior to analysis. These haematological parameters were assessed: packed cell volume (PCV, \%) following Mukherjee (2005), red blood cell count (RBC $\times$ 
$10^{6} / \mu \mathrm{L}$ ) following Dacie \& Lewis (2000), white blood cell count (WBC $\times 10^{3} / \mu \mathrm{L}$ ) following Holfbrand \& Petit (2000), haemoglobin $(\mathrm{Hb}, \mathrm{g} / \mathrm{dL})$ following Cheesbrough (2001), white blood cell differentials (heterophils, lymphocytes, eosinophils, monocytes, basophils; all \%), mean corpuscular haemoglobin concentration $(\mathrm{MCHC}, \mathrm{g} / \mathrm{dL})$, mean corpuscular haemoglobin $(\mathrm{MCH}, \mathrm{pg})$, mean corpuscular volume $\left(\mathrm{MCV}, \mu \mathrm{m}^{3}\right)$ and platelets (PLAT, $\times 10^{3} / \mu \mathrm{L}$ ) using a haemo-analyser (Sysmex Hematology Analyser, XS-500i, Sysmex Europe $\mathrm{GmbH}$, Norderstedt, Germany). The serum biochemical assay was carried out by spectrophotometry. The parameters included total serum proteins $(\mathrm{g} / \mathrm{L})$, albumin $(\mathrm{g} / \mathrm{L})$, globulins $(\mathrm{g} / \mathrm{L})$, alkaline phosphate (units $(\mathrm{U}) / \mathrm{L})$, aspartate transferase $(\mathrm{U} / \mathrm{L})$ and alanine transferase $(\mathrm{U} / \mathrm{L})$.

Table 3 Pimarane-type diterpenoid compound candidates detected in false yam tubers (UPLC-MS)

\begin{tabular}{|c|c|c|c|}
\hline No. & Name & $\begin{array}{l}\text { Molecular } \\
\text { formula }\end{array}$ & $\begin{array}{c}\text { Measured }[\mathrm{M}-\mathrm{H}] /[\mathrm{M}+\mathrm{H}]^{+} \text {monoisotopic mass }(\mathrm{u}) \\
\mathrm{MS}(\mathrm{ppm}) \text { in brackets }\end{array}$ \\
\hline 01 & Icacine & $\mathrm{C}_{22} \mathrm{H}_{30} \mathrm{O}_{6} \mathrm{~N}$ & $404.20810(0.592)$ \\
\hline 02 & 17-Hydroxyicacinol* & $\mathrm{C}_{20} \mathrm{H}_{26} \mathrm{O}_{8}$ & $395.17029(0.622)$ \\
\hline 03 & $14 \alpha-$ Methoxyhumirianthol & $\mathrm{C}_{21} \mathrm{H}_{28} \mathrm{O}_{7}$ & $391.17622(-0.016)$ \\
\hline 04 & Icacinol* & $\mathrm{C}_{20} \mathrm{H}_{26} \mathrm{O}_{7}$ & $379.17535(0.581)$ \\
\hline 05 & $7 \alpha$-Hydroxyicacenone & $\mathrm{C}_{19} \mathrm{H}_{20} \mathrm{O}_{8}$ & $375.10840(-0.375)$ \\
\hline 06 & Icaceine & $\mathrm{C}_{22} \mathrm{H}_{32} \mathrm{O}_{4} \mathrm{~N}$ & $374.23340(2.178)$ \\
\hline \multirow[t]{3}{*}{07} & Icacinlactone $\mathrm{C}^{*}$ & $\mathrm{C}_{20} \mathrm{H}_{20} \mathrm{O}_{7}$ & $373.12853(0.940)$ \\
\hline & Icacinlactone $\mathrm{D}^{*}$ & & \\
\hline & $7 \beta$-Hydroxyicacinlactone $\mathrm{B}^{*}$ & & \\
\hline \multirow[t]{2}{*}{08} & Icacinlactone L & $\mathrm{C}_{20} \mathrm{H}_{18} \mathrm{O}_{7}$ & 369.09727 (-1.859) \\
\hline & Icacintrichantholide & & \\
\hline 09 & \multirow{3}{*}{$\begin{array}{l}\text { Humirianthol } \\
2 \beta \text { - } \\
\text { Hydroxyhumirianthenolide C } \\
\text { Icacenone }\end{array}$} & $\mathrm{C}_{20} \mathrm{H}_{26} \mathrm{O}_{6}$ & $361.16536(-0.005)$ \\
\hline 10 & & $\mathrm{C}_{19} \mathrm{H}_{22} \mathrm{O}_{7}$ & $361.12958(0.841)$ \\
\hline \multirow[t]{3}{*}{11} & & $\mathrm{C}_{19} \mathrm{H}_{20} \mathrm{O}_{7}$ & $359.11371(0.233)$ \\
\hline & Icacinlactone F & & \\
\hline & Icacinlactone $\mathrm{K}$ & & \\
\hline 12 & Icacinlactone B & $\mathrm{C}_{20} \mathrm{H}_{20} \mathrm{O}_{6}$ & $355.11856(-0.427)$ \\
\hline \multirow[t]{4}{*}{13} & Humirianthenolide $\mathrm{C}$ & $\mathrm{C}_{19} \mathrm{H}_{22} \mathrm{O}_{6}$ & $345.13434(-0.063)$ \\
\hline & Icacinlactone G & & \\
\hline & Icacinlactone I & & \\
\hline & Icacinlactone J & & \\
\hline \multirow[t]{2}{*}{14} & Icacinlactone E & $\mathrm{C}_{19} \mathrm{H}_{20} \mathrm{O}_{6}$ & $343.11856(-0.442)$ \\
\hline & Icacintrichanone & & \\
\hline 15 & 12-Hydroxyicacinlactone A & $\mathrm{C}_{19} \mathrm{H}_{18} \mathrm{O}_{6}$ & $341.10260(-1.353)$ \\
\hline 16 & Icacinlactone A & $\mathrm{C}_{19} \mathrm{H}_{18} \mathrm{O}_{5}$ & $325.10746(-2.113)$ \\
\hline
\end{tabular}

UPLC-MS: ultra-performance liquid chromatography-mass spectrometry

${ }^{*}$ Detected as $[\mathrm{M}+\mathrm{H}]^{+}$

Data were assessed for normality by the Shapiro-Wilk test and for constant variance by the Bartlett test. Normally distributed data with homogenous variance were subjected to one-way analysis of variance (ANOVA) and post-hoc Tukey's honest significant difference (HSD) test with 95\% family-wise confidence level. All other data were subjected to the Kruskal-Wallis rank sum test, followed by the Wilcoxon rank sum test for pairwise comparison of treatments. No block effect was observed and therefore was not further considered in the models. First step analyses included the control and the false yam tuber meals without additional WC (treatments C, RFY-0, SFY-0), next step analyses compared the false yam tuber meals without (RFY-0, SFY-0) and with additional WC (RFY-30, SFY-30, RFY-60, SFY-60). Finally, MCV values were fitted into a simple linear regression model to predict relationship with increasing inclusion level of 
charcoal to the false yam meals (RFY, SFY). All statistical analyses were performed in R version 3.3.0 (The $\mathrm{R}$ Foundation for Statistical Computing). The same software was used to created graphs.

\section{Results}

Replacing part of the commercial broiler feed with SFY tuber meal reduced bird weight gain $(P<0.001)$ (Table 4), while RFY tuber meal at the studied inclusion level had no effect on bird weight gain.

The addition of WC to false yam tuber meals did not show any effect $(P>0.05)$, positive or negative, on broiler chickens' ADG (Table 5) and hence final bodyweight.

Table 4 Performances and mortality rate of experimental broiler chickens fed a control diet and various false yam tuber meals without wood charcoal

\begin{tabular}{lccccccccccc}
\hline & \multicolumn{3}{c}{ Control (C) } & \multicolumn{3}{c}{ RFY-0 } & \multicolumn{3}{c}{ SFY-0 } & P-value \\
\cline { 2 - 11 } & Median & Min. & Max. & Median & Min. & Max. & Median & Min. & Max. & \\
\hline Weight gain (g/d) & $38.9^{\mathrm{a}}$ & 27.3 & 51.6 & $38.3^{\mathrm{a}}$ & 29.5 & 54.8 & $31.1^{\mathrm{b}}$ & 24.6 & 37.9 & 0.001 \\
Feed intake (g/d) & 132.0 & 117.2 & 138.0 & 125.0 & 115.7 & 185.0 & 138.1 & 128.1 & 171.4 & 0.472 \\
Feed : gain ratio & 3.3 & 3.1 & 3.5 & 3.1 & 2.4 & 5.3 & 4.5 & 4.0 & 5.7 & 0.093 \\
Mortality rate & 0.09 & 0.00 & 0.33 & 0.17 & 0.00 & 0.50 & 0.00 & 0.00 & 0.17 & 0.352 \\
\hline
\end{tabular}

Control: commercial broiler finisher diet; RFY-0: raw false yam tuber meal (50 g/kg; RFY) without wood charcoal (WC); SFY-0: false yam tuber meal soaked in water (150 g/kg; SFY) without WC. Kruskal-Wallis test and post-hoc Wilcoxon rank sum test. Min.: minimum; Max.: maximum

Table 5 Effect of varying inclusion levels of wood charcoal to false yam tuber meals on performances and mortality rate of experimental broiler chickens

\begin{tabular}{lccccccccccccc}
\hline & \multicolumn{3}{c}{ Weight gain (g/d) } & \multicolumn{3}{c}{ Feed intake (g/d) } & \multicolumn{2}{c}{ Feed : gain ratio } & \multicolumn{3}{c}{ Mortality rate } \\
\cline { 2 - 15 } & Median & Min. & Max. & Median & Min. & Max. & Median & Min. & Max. & Median & Min. & Max. \\
\hline RFY-0 & 38.3 & 29.5 & 54.8 & 125.0 & 115.7 & 184.7 & 3.1 & 2.4 & 5.3 & 0.17 & 0.00 & 0.50 \\
RFY-30 & 45.6 & 30.1 & 54.3 & 142.1 & 137.8 & 143.6 & 3.3 & 2.9 & 3.7 & 0.17 & 0.00 & 0.33 \\
RFY-60 & 38.0 & 29.9 & 52.1 & 143.6 & 135.1 & 151.9 & 3.6 & 3.3 & 4.0 & 0.00 & 0.00 & 0.00 \\
$P$-value & 0.252 & & & 0.368 & & & 0.309 & & & 0.085 & & \\
\hline SFY-0 & 38.3 & 29.5 & 54.8 & 138.1 & 128.1 & 171.4 & 4.5 & 4.0 & 5.7 & 0.00 & 0.00 & 0.17 \\
SFY-30 & 45.6 & 30.1 & 54.3 & 143.6 & 139.8 & 173.7 & 5.1 & 4.5 & 6.2 & 0.00 & 0.00 & 0.17 \\
SFY-60 & 38.0 & 30.0 & 52.1 & 132.3 & 112.8 & 140.0 & 4.4 & 4.2 & 4.9 & 0.00 & 0.00 & 0.00 \\
$P$-value & 0.387 & & & 0.118 & & & 0.309 & & & 0.577 & &
\end{tabular}

RFY-0: raw false yam tuber meal (50 g/kg; RFY) without wood charcoal (WC); RFY-30 and RFY-60: raw false yam tuber meal with $30 \mathrm{~g} / \mathrm{kg}$ and $60 \mathrm{~g} / \mathrm{kg}$ wood charcoal; SFY-0: false yam tuber meal soaked in water (150 g/kg; SFY) without WC; SFY-30 and SFY-60: soaked false yam tuber meal with $30 \mathrm{~g} / \mathrm{kg}$ and $60 \mathrm{~g} / \mathrm{kg}$ wood charcoal. Kruskal-Wallis test and posthoc Wilcoxon rank sum test. Min.: minimum; Max.: maximum

After the adaptation week, bird bodyweights already varied, depending on the diet (Figure 1). If the diets without WC are compared, the highest bodyweights at the start of the first experimental week (week 1) were found for birds fed $\mathrm{C}$. Birds fed RFY-0 diets had lower bodyweights $(P<0.01)$ compared with $\mathrm{C}$. The lowest bodyweights were observed for birds fed SFY-0 $(P<0.001)$ for which the mean bodyweight remained lowest over the four experimental weeks, resulting in 19\% lower final bodyweight compared with birds fed $C$ $(P<0.05)$. In contrast, the final bodyweights of birds fed RFY-0 were similar to those of the control diet $(P>0.05)$. As could be expected from these results, no effects of WC on bird bodyweights were obtained $(P>0.05)$. 


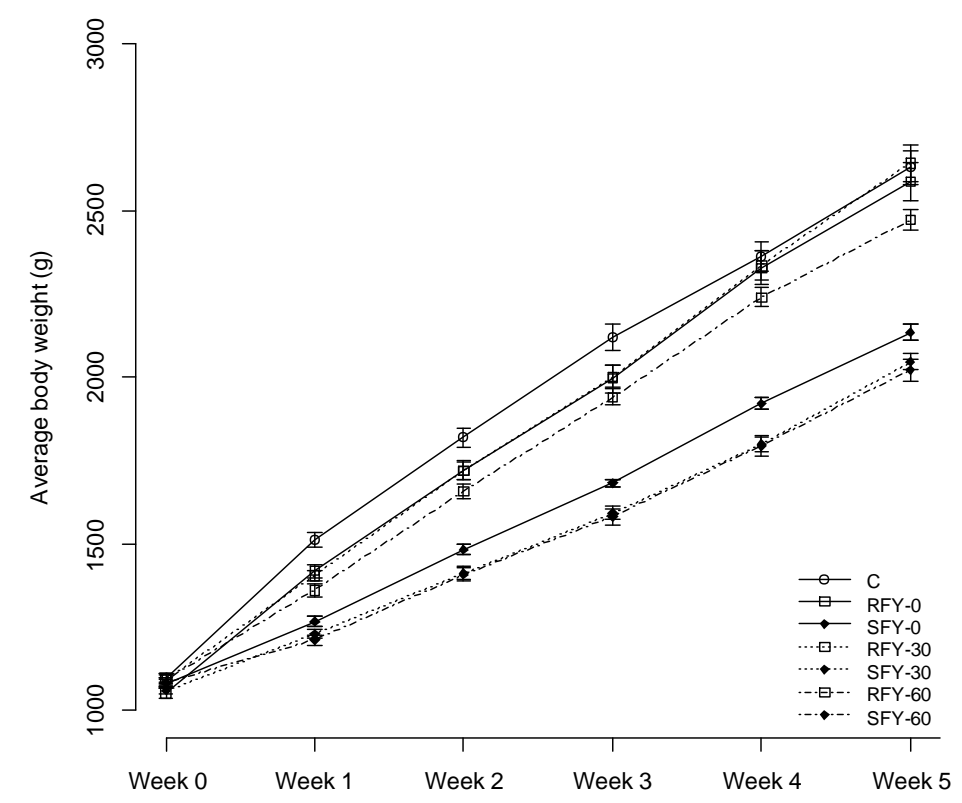

C: commercial broiler finisher diet (control); RFY-0: raw false yam tuber meal (50 g/kg; RFY) without wood charcoal (WC); SFY-0: false yam tuber meal soaked in water (150 g/kg; SFY) without WC; RFY-30: RFY with $30 \mathrm{~g} / \mathrm{kg}$ WC; SFY30: SFY with $30 \mathrm{~g} / \mathrm{kg} \mathrm{WC;} \mathrm{RFY-60:} \mathrm{RFY} \mathrm{with} 60 \mathrm{~g} / \mathrm{kg}$ WC; SFY-60: SFY with $60 \mathrm{~g} / \mathrm{kg} \mathrm{WC}$

Figure 1 Average bodyweight of broiler chickens at the start of each week

The average DFI, FCR and mortalities did not differ among dietary treatments without WC $(P>0.05)$ (Table 4). As for ADG and bodyweight, no effect of WC at the studied inclusion levels on these variables was observed $(P>0.05)$ (Table 5). However, DFI increased more sharply for false yam tuber meals compared with $\mathrm{C}$ in experimental weeks 2 to 4, particular for SFY-0 and SFY-30 (Figure 2). As a consequence, FCR was poorest in broiler chickens fed SFY, particularly SFY-30.

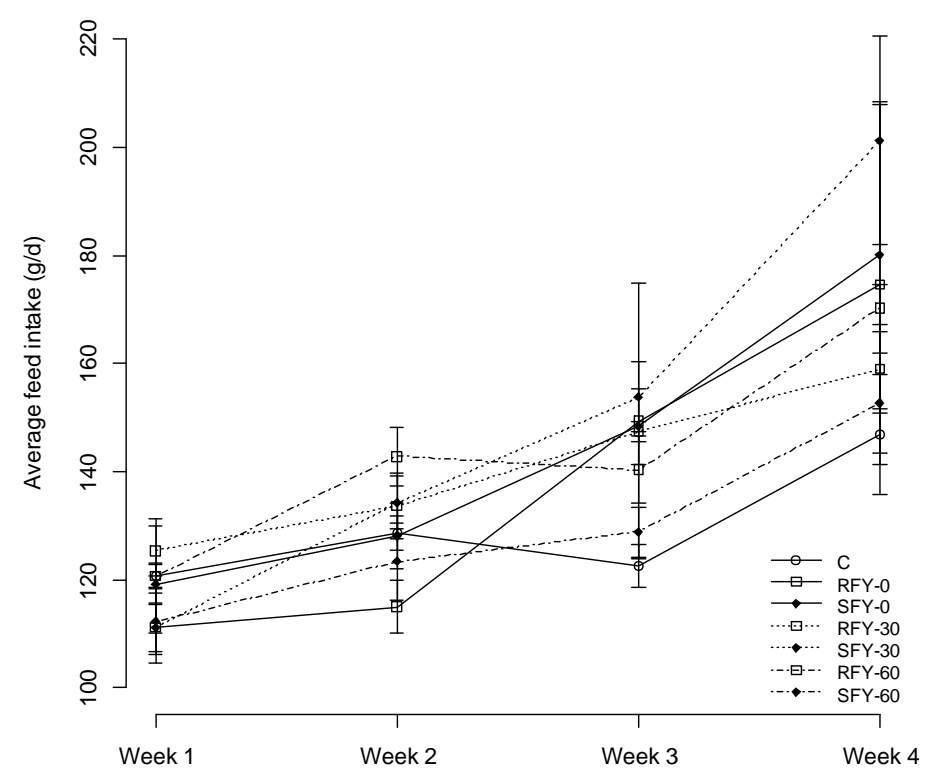

C: commercial broiler finisher diet (control); RFY-0: raw false yam tuber meal (50 g/kg; RFY) without wood charcoal (WC); SFY-0: false yam tuber meal soaked in water (150 g/kg; SFY) without WC; RFY-30: RFY with $30 \mathrm{~g} / \mathrm{kg}$ WC; SFY30: SFY with $30 \mathrm{~g} / \mathrm{kg}$ WC; RFY-60: RFY with $60 \mathrm{~g} / \mathrm{kg}$ WC; SFY-60: SFY with $60 \mathrm{~g} / \mathrm{kg}$ WC

Figure 2 Average daily feed intake of broiler chickens for each experimental week 
With regard to haematological parameters, the authors observed no effects of false yam tuber meals, except a decrease in MCV and an increase in RBC of birds fed SFY- 0 compared with birds fed C and RFY-0 diet $(P<0.05)$. Furthermore, basophils were detected in the blood of birds fed SFY-0 (Table 6). The inclusion of WC in false yam tuber meals could counterbalance the negative effect in MCV. MCV values for birds fed RFY-30, RFY-60, SFY-30 and SFY-60 were not different from C. A linear increase in MCV was realized with increasing levels of WC. In contrast, no effect of varying levels of WC was observed for RBC values of birds fed the SFY meal (Figure 3).

Table 6 Haematology of experimental broiler chickens fed a control diet and various false yam tuber meals without wood charcoal (arithmetic means)

\begin{tabular}{lcccccc}
\hline Variable & Unit & C & RFY-0 & SFY-0 & SEM & P-value \\
\hline $\mathrm{PCV}^{\mathrm{a}}$ & $\%$ & 32.77 & 32.93 & 32.87 & 0.229 & 0.334 \\
$\mathrm{RBC}^{\mathrm{a}}$ & $\times 10^{6} / \mu \mathrm{L}$ & $2.37^{\mathrm{c}}$ & $2.66^{\mathrm{c}}$ & $2.78^{\mathrm{d}}$ & 0.071 & 0.023 \\
$\mathrm{Hb}^{\mathrm{a}}$ & $\mathrm{g} / \mathrm{dL}$ & 7.73 & 7.93 & 8.23 & 0.156 & 0.482 \\
$\mathrm{MCHC}^{\mathrm{a}}$ & $\mathrm{g} / \mathrm{dL}$ & 23.67 & 24.10 & 25.03 & 0.453 & 0.484 \\
$\mathrm{MCH}^{\mathrm{a}}$ & $\mathrm{pg}$ & 32.67 & 29.93 & 29.70 & 0.605 & 0.068 \\
$\mathrm{MCV}^{\mathrm{b}}$ & $\mu \mathrm{m}^{3}$ & $138.63^{\mathrm{c}}$ & $124.10^{\mathrm{c}}$ & $118.37^{\mathrm{d}}$ & 3.469 & 0.032 \\
Platelets $^{\mathrm{a}}$ & $\times 10^{3} / \mu \mathrm{L}$ & 11.33 & 10.33 & 11.33 & 1.691 & 0.971 \\
$\mathrm{WBC}^{\mathrm{a}}$ & $\times 10^{3} / \mathrm{LL}$ & 8.11 & 13.29 & 11.02 & 1.567 & 0.460 \\
Heterophils $^{\mathrm{b}}$ & $\%$ & 51.00 & 50.67 & 50.00 & 0.747 & 0.888 \\
Lymphocytes $^{\mathrm{a}}$ & $\%$ & 48.67 & 48.67 & 48.00 & 0.747 & 0.935 \\
Eosinophils $^{\mathrm{b}}$ & $\%$ & 0.00 & 0.00 & 0.33 & 0.111 & 0.368 \\
Monocyte $^{\mathrm{b}}$ & $\%$ & 0.33 & 0.67 & 1.00 & 0.289 & 0.656 \\
Basophils $^{\mathrm{b}}$ & $\%$ & 0.00 & 0.00 & 0.67 & 0.147 & 0.102
\end{tabular}

C: commercial broiler finisher diet (control); RFY-0: raw false yam tuber meal $(50 \mathrm{~g} / \mathrm{kg}$; RFY) without wood charcoal (WC); SFY-0: false yam tuber meal soaked in water (150 g/kg; SFY) without WC. PCV: packed cell volume; RBC: red blood cell count; $\mathrm{Hb}$ : haemoglobin; $\mathrm{MCHC}$ : mean corpuscular haemoglobin concentration; $\mathrm{MCH}$ : mean corpuscular haemoglobin; MCV: mean corpuscular volume; WBC: white blood cell count. SEM: standard error of mean

${ }^{a}$ ANOVA and post-hoc Tukey HSD test

${ }^{\mathrm{b}}$ Kruskal-Wallis test

Similar to haematological variables, the type of false yam tuber meal did not affect blood serum proteins, globulin, alkaline phosphate, aspartate transferase and alanine transferase levels of broiler chickens $(P>0.05)$ (Table 7). Furthermore, no effects of increasing level of WC to false yam tuber meals were observed for serological parameters $(P>0.05)$.

\section{Discussion}

The RFY at $50 \mathrm{~g} / \mathrm{kg}$ inclusion level might be an option to replace part of commercial broiler feed in northern Ghana and other countries where Icacina oliviformis is native. No effect of RFY was observed on bird production performances. However, a higher inclusion of RFY would lead to a reduction in broiler production performances (Teye et al., 2011). In contrast, MCV in the blood of experimental birds was reduced if no WC was added, but values were still within the reference range of 100-139 $\mathrm{m}^{3}$ (Greenacre \& Morishita, 2014). The MCV defines the size of RBC and is used to morphologically classify anaemia. Reduced MCV might be an indicator of microcytic anaemia (Sarma, 1990). Nevertheless, experimental birds fed the RFY diet did not show any signs of anaemia. Finally, toxic substances in RFY might lead to slightly higher mortality rates.

In contrast to the results obtained for RFY, the inclusion of SFY in commercial broiler feed at the investigated level of $150 \mathrm{~g} / \mathrm{kg}$ is not recommended because of the negative effects on bird production performance. Limiting the inclusion level to $120 \mathrm{~g} / \mathrm{kg}$, as suggested by Dei et al. (2015b), might be an option to avoid negative effects on performance characteristics. In the current study, the decrease in growth performance of birds fed SFY could not be compensated by a comparably higher DFI, which was particularly observed at the end of the finisher phase. This could be explained by the relatively low CP concentrations of 
SFY tuber meals, which were below the recommended values of $200 \mathrm{~g} / \mathrm{kg}$ (4-6 weeks of age) and $180 \mathrm{~g} / \mathrm{kg}$ (above 6 weeks of age) for broiler chickens (Merck Veterinary Manual, 2016; National Research Council, 1994). Additionally, Bregendahl et al. (2002), among others, revealed a lower growth performance, higher feed intake and thus poorer FCR of broiler chickens fed low-protein diets. Hence, more feed and feed additives might be needed to compensate for the low energy and protein content of false yam meals (Dei et al., 2015b) and to allow birds to counterbalance the toxic effect of terpenic constituents in false yam tubers (Nersesian et al., 2012). In addition to the time needed to soak false yam tubers, this would increase costs and thereby potentially limit the benefits of false yam in poultry production.

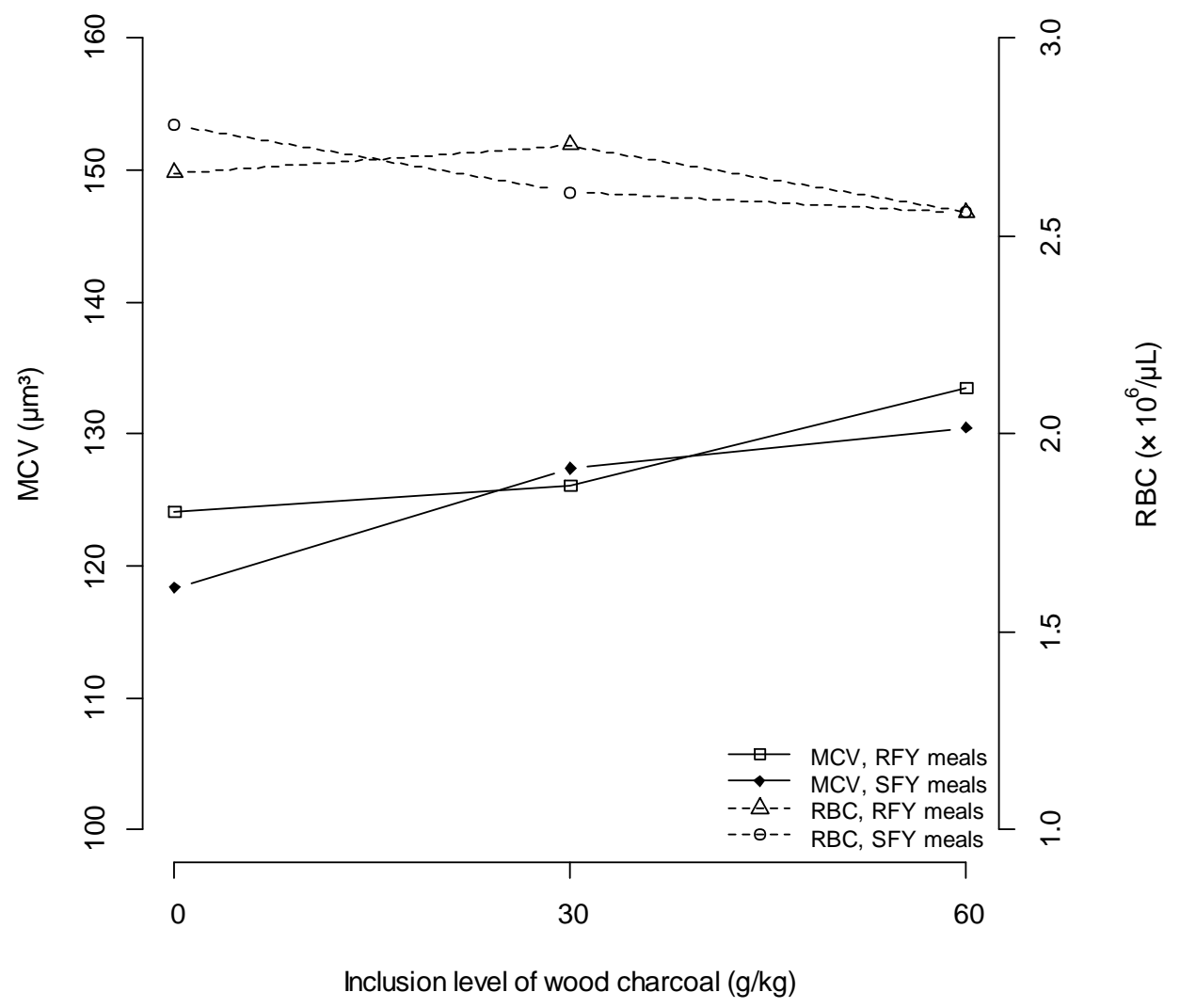

RFY: raw false yam tuber meal at $50 \mathrm{~g} / \mathrm{kg}$ substitution level; SFY: soaked false yam tuber meal at $150 \mathrm{~g} / \mathrm{kg}$ substitution level in relation to increasing level of included wood charcoal $(0 \mathrm{~g} / \mathrm{kg}, 30 \mathrm{~g} / \mathrm{kg}, 60 \mathrm{~g} / \mathrm{kg})$

Figure 3 Mean corpuscular volume and red blood cell count of broiler chickens fed false yam tuber meals

Table 7 Serology of experimental broiler chickens fed a control diet and various false yam tuber meals without wood charcoal (arithmetic means)

\begin{tabular}{lcccccc}
\hline & Unit & C & RFY-0 & SFY-0 & SEM & P-value \\
\hline Total protein & $\mathrm{g} / \mathrm{L}$ & 35.40 & 32.80 & 31.57 & 1.286 & 0.526 \\
Albumin & $\mathrm{g} / \mathrm{L}$ & 16.17 & 13.77 & 13.40 & 0.563 & 0.067 \\
Globulin & $\mathrm{g} / \mathrm{L}$ & 19.20 & 19.07 & 18.20 & 1.008 & 0.929 \\
ALK & $\mathrm{U} / \mathrm{L}$ & 155.10 & 154.27 & 168.27 & 7.730 & 0.764 \\
ASP & $\mathrm{U} / \mathrm{L}$ & 126.50 & 91.53 & 142.50 & 18.699 & 0.589 \\
ALA & $\mathrm{U} / \mathrm{L}$ & 10.97 & 7.87 & 8.40 & 1.287 & 0.640
\end{tabular}

C: commercial broiler finisher diet (control), RFY-0: raw false yam tuber meal (50 g/kg; RFY) without wood charcoal (WC); SFY-0: false yam tuber meal soaked in water (150 g/kg; SFY) without WC. ALK: alkaline phosphate; ASP: aspartate transferase; ALA: alanine transferase. U: unit. SEM: standard error of the mean. ANOVA test. 
Despite their low CP concentrations, the false yam tuber meals met the requirements for most limiting amino acids, as shown by the amino acid profiles of the diets, with the exception of the threonine concentrations of SFY-30 and SFY-60, which were below the recommendations set by NRC (1994). This lack might explain the negative effect on total serum protein, albumin and globulin concentrations, which were below the reference ranges (Greenacre \& Morishita, 2014). A decrease in blood proteins reflects decreased protein synthesis owing to malnutrition or lack of essential amino acids, which are required for protein synthesis (Shikora, 2002). Although the authors observed such a decrease for both types of false yam tuber meals, differences were insignificant to the control diet.

Furthermore, terpenes could be an antagonist of essential amino acid receptors in poultry. However, the mechanisms of interaction and effects of terpenes in Icacina oliviformis on bird physiology are largely unknown and additional studies are needed to clearly confirm the negative effects of false yam tuber meals on bird performance, serological parameters and consequently health status. In general, studies revealed a large variety of properties of extracts of Icacina species. Ethanol extracts of Icacina trichantha were reported to protect the kidneys and livers of rats poisoned with tetrachloromethane (Asuzu \& Abubakar, 1995). Hydroalcoholic extracts of Icacina trichantha tubers showed an inhibition of croton oil-induced ear edema in mice (Asuzu et al., 1999). Some subfractions of methanol extracts of leaves of Icacina oliviformis inhibited the growth of chloroquine resistant strains of Plasmodium falciparum, which cause malaria in humans (Sarr et al., 2011). Ethanol and water extracts of leaves Icacina oliviformis showed antimicrobial activities against Escherichia coli, Staphylococcus aureus, Streptococcus spp, Candida albicans and Klebsiella pneumonia (Shagal \& Kubmarawa, 2013). Unfortunately, all these results are preliminary, because secondary metabolites have not yet been identified; nor have their properties been tested and proven in in vivo studies. In contrast, Zhao et al. (2014) reported cytotoxic activities of isolated, purified and identified pimarane-type diterpenoids from tubers of Icacina trichantha. Diterpene humirianthenolide $\mathrm{C}$ in particular showed activity against the human melanoma cancer (MDA-MB-435) and human breast cancer cells (MDA-MB-231) (Zhao et al., 2014).

Soaking false yam tubers in water to remove terpenes before feeding, as suggested by Dei et al. (2015b), had almost no effect on the amount of the lipophilic $n$-hexane subfractions, but starting with the $\mathrm{CHCl}_{3}$-subfraction, all other subfractions showed smaller mass data for the soaked biological material than for raw. This demonstrates that water removes hydrophilic compounds from the false yams tubers more easily than lipophilic ones.

Including WC along with false yam tuber meals partially attenuated the anti-nutritive effects of Icacina oliviformis, particularly for raw tubers. However, adding WC with false yam tuber meals further reduces the energy and nutrient density per unit feed, which is reflected in lowest final bodyweights and blood protein of birds fed SFY with $30 \mathrm{~g} / \mathrm{kg}$ and $60 \mathrm{~g} / \mathrm{kg}$ added WC. Although the inclusion of WC in false yam diets did not further increase the feed intake of birds of these groups in the current study, higher feed intakes and lower FCRs obtained in other studies do not justify the inclusion of WC in broiler diets (Odunsi et al., 2007). A study by Chu et al. (2013) revealed a negative effect of bamboo charcoal on total blood protein in fattening pigs, while, contrary to the results of the current study, a positive effect on pig growth performance was observed. Finally, the inclusion of WC in livestock feed is supportable, only if sustainable sources of biomass are used as feedstock for its production and there are no alternative uses of this material. A review by Duku et al. (2011) showed that Ghana owns a large variety of potential feedstock for the production of charcoal, including agricultural waste (for example rice husks and maize cobs) and forestry residues, as well as wood processing waste such as sawdust.

\section{Conclusions}

Anti-nutritional substances contained in SFY at the studied substitution level are harmful to the birds, irrespective of whether WC is added or not. In contrast, including $50 \mathrm{~g} / \mathrm{kg}$ RFY had no effect on the parameters, except for mortality, which tended to be slightly higher. Wood charcoal could possibly reduce mortality in birds fed RFY, but only at inclusion levels higher than $30 \mathrm{~g} / \mathrm{kg}$. It would be of interest to verify the effects of false yam tuber meals and WC on performances and blood parameters of local avian genetic resources because of their adaptation to adverse climatic conditions and husbandry practices and their role in food security of urban and rural households in northern Ghana.

\section{Acknowledgements}

This work was carried out as part of the UrbanFood ${ }^{\text {Plus }}$ Project, jointly funded by the German Federal Ministry of Education and Research (BMBF) and the German Federal Ministry for Economic Cooperation and Development (BMZ) under the initiative GlobE-Research for the Global Food Supply, grant number 031A242-A. The sponsor had no role in the design of the study, in the collection, analyses, or interpretation of data, in the writing of the manuscript, and in the 
decision to publish the results. The authors' special thanks go to George Nyarko, dean of the Faculty of Agricultural Sciences of the University for Development Studies in Tamale, Ghana, for supporting this study.

\section{Authors' Contributions}

CS and RR coordinated the project design and were in charge of writing the manuscript. BA and HKD were in charge of supervising the implementation of the study at UDS Nyankpala. LA, ARS and AM were in charge of data collection; AM was responsible for laboratory tests of the blood samples. RCM and DH were responsible for laboratory analysis of terpenic constituents of false yam tuber meals and interpreting related results. RR coordinated laboratory analysis of other feed constituents including the amino acid profiles. All co-authors participated in results, statistics and interpretation.

\section{Conflict of Interest Declaration}

The authors declare that there are no conflicts of interest.

\section{References}

Alhassan, M., 2015. Effect of soaked false yam (Icacina oliviformis) seed meal on laying performance of chicken. Glob. J. Anim. Scientific Res. 3(3), ISSN 2345-4385. Available at: http://www.gjasr.com/index.php/GJASR/article/view/272. Date accessed: 3 August 2017.

Ansah, T., Emelia, A.A., Deku, G. \& Karikari, P.K. 2012. Evaluation of false yam (Icacina oliviformis) leaves on the growth performance of weaner rabbits (Oryctolagus cuniculus). Online J. Anim. Feed Res. 2(1), 76-79.

Asuzu, I.U. \& Abubakar, I.I., 1995. The effects of Icacina trichantha tuber extract on the nervous system. Phytother. Res. 9, 21-25

Asuzu, I.U., Sosa, S. \& Della Loggia, R., 1999. The anti-inflammatory activity of Icacina trichantha tuber. Phytomedicine 6, 267-272. doi:10.1016/S0944-7113(99)80019-1.

Bregendahl, K., Sell, J. \& Zimmerman, D., 2002. Effect of low-protein diets on growth performance and body composition of broiler chicks. Poult. Sci. 81, 1156-1167.

Byng, J.W., Bernardini, B., Joseph, J.A., Chase, M.W. \& Utteridge, T.M.A., 2014. Phylogenetic relationship of Icacinaceae focusing on the vining genera. Bot. J. Linn. Soc. 176, 277-294.

Cheesbrough, M., 2001. District laboratory practice in tropical countries. Cambridge Univ. Press, Cambridge, UK.

Chu, G.M., Kim, J.H., Kim, H.Y., Ha. J.H., Jung, M.S., Song, Y., Cho, J.H., Lee, S.J., Ibrahim, R.I.H., Lee, S.S. \& Song, Y.M., 2013. Effects of bamboo charcoal on the growth performance, blood characteristics and noxious gas emissions in fattening pigs. J. Appl. Anim. Res. 41(1), 48-55.

Dacie, J. V. \& Lewis, L.M., 2000. Practical Haematology. 9th ed. Churchill Livingstone, Edinburgh, UK.

Dei, H., Ajigepungu, W. \& Mohammed, A., 2015a. Growth performance of broilers fed varying levels of soaked false yam (Icacina oliviformis) tuber meal. Ghana J. Sci. Technol. Dev. 3, 72-76.

Dei, H.K., Asare, A.I. \& Mohammed, A., 2015b. Growth response of broiler chickens fed false yam (Icacina oliviformis) tuber soaked in saltpetre solution. Ghana J. Sci. Technol. Dev. 3, 44-46.

Dei, H.K., Bacho, A., Adeti, J. \& Rose, S.P., 2011. Nutritive value of false yam (Icacina oliviformis) tuber meal for broiler chickens. Poul. Sci. 90, 1239-1244.

Duku, M.H., Gu, S. \& Hagan, E.B., 2011. Biochar production potential in Ghana - A review. Renew. Sustain. Energy Rev. 15, 3539-3551.

Gerlach, H. \& Schmidt, H.-P., 2012. Biochar in poultry farming. Ithaka J. 1, 262-264.

Greenacre, C.B. \& Morishita, T.Y., 2014. Backyard poultry medicine and surgery. Wiley Blackwell, Hoboken, New Jersey, US.

Guo, B., Onakpa, M.M., Huang, X.-J., Santarsiero, B.D., Chen, W.-L., Zhao, M., Zhang, X.-Q., Swanson, S.M., Burdette, J.E. \& Che, C.-T., 2016. Di-nor - and 17-nor-pimaranes from Icacina trichantha. J. Nat. Prod. 79, 1815-1821. doi:10.1021/acs.jnatprod.6b00289.

Holfbrand, A. V. \& Petit, J.E.,2000. Essential haematology. 4th ed. Blackwell Science, Mississauga, Ontario, Canada.

Hölscher, D., Vollrath, A., Kai, M., Dhakshinamoorthy, S., Menezes, R. C., Svatoš, A., Schubert, U. S., Buerkert, A. \& Schneider, B., 2017. Local phytochemical response of Musa acuminata x balbisiana Colla cv. 'Bluggoe' (ABB) to colonization by Sternorrhyncha. Phytochemistry 133, 26-32.

Kana, J.R., Teguia, A., Mungfu, B.M. \& Tchoumboue, J., 2011. Growth performance and carcass characteristics of broiler chickens fed diets supplemented with graded levels of charcoal from maize cob or seed of Canarium schweinfurthii Engl. Trop. Anim. Health Prod. 43, 51-56. doi:10.1007/s11250-010-9653-8.

Kato-Noguchi, H. \& Peters, R.J., 2013. The role of momilactones in rice allelopathy. J. Chem. Ecol. 39, $175-185$. doi:10.1007/s10886-013-0236-9.

Kim, S.J., Park, H.R., Park, E. \& Lee, S.C., 2007. Cytotoxic and antitumor activity of momilactone B from rice hulls. J. Agric. Food Chem. 55, 1702-1706. doi:10.1021/jf062020b.

Kutlu, H.R., Ünsal, I. \& Görgülü, M., 2001. Effects of providing dietary wood (oak) charcoal to broiler chicks and laying hens. Anim. Feed Sci. Technol. 90, 213-226. doi:10.1016/S0377-8401(01)00205-X.

Liu, N., Wang, S. \& Lou, H., 2012. A new pimarane-type diterpenoid from moss Pseudoleskeella papillosa (Lindb.) Kindb. Acta Pharm. Sin. B 2, 256-259. doi:10.1016/j.apsb.2012.03.003.

Merck Veterinary Manual, 2016. No one breeds knowledge like we do! Merck \& Co., 11th edition. Kenilworth, New Jersey, US.

Mukherjee, K. L., 2005. Manual for Routine Diagnostic Tests. Vol. 1. Tata McGraw-Hill, New Delhi, India. 
National Research Council, 1994. Nutrient requirements of poultry. 9th rev. ed. National Academy Press, Washington, DC, USA.

National Research Council (NRC), 2008. Lost crops of Africa: Volume III: Fruits. Washington, DC: The National Academies Press. https://doi.org/10.17226/11879.

Nersesian, C.L., Banks, P.B., Simpson, S.J. \& McArthur, C., 2012. Mixing nutrients mitigates the intake constraints of a plant toxin in a generalist herbivore. Behav. Ecol. 23, 879-888. doi:10.1093/beheco/ars049.

Nozaki, H., Hayashi, K., Nishimura, N., Kawaide, H., Matsuo, A. \& Takaoka, D., 2007. Momilactone A and B as allelochemicals from moss Hypnum plumaeforme: First occurrence in bryophytes. Biosci. Biotechnol. Biochem. 71, 3127-3130. doi:10.1271/bbb.70625.

Odunsi, A.A., Oladele, T.O., Olaiya, A.O. \& Onifade, O.S., 2004. Response of broiler chickens to wood charcoal and vegetable oil based diets. World J. Agric. Sci. 3(5), 572-575

Onakpa, M., Zhao, M., Gödecke, T., Chen, W., Che, C., Santarsiero, B.D., Swanson, S.M. \& Uzoma Asuzu, I., 2014. Cytotoxic $(9 \beta \mathrm{H})$-pimarane and $(9 \beta \mathrm{H})$-17-norpimarane diterpenes from the tuber of Icacina trichantha. Chem. Biodivers. 11, 1914-1922. doi:10.1002/cbdv.201400151.

Sarma, P.R., 1990. Red cell indices. In: H. Walker, W.D. Hall, J.W. Hurst (eds). Clinical methods: The history, physical, and laboratory examinations. 3rd edition, chapter 152. Butterworths, Boston. Available from: https://www.ncbi.nlm.nih.gov/books/NBK260/.

Sarr, S.O., Perrotey, S., Fall, I., Ennahar, S., Zhao, M., Diop, Y.M., Candolfi, E. \& Marchioni, E., 2011. Icacina senegalensis (Icacinaceae), traditionally used for the treatment of malaria, inhibits in vitro Plasmodium falciparum growth without host cell toxicity. Malar. J. 10, 85. doi:10.1186/1475-2875-10-85.

Shagal, M.H. \& Kubmarawa, D., 2013. Antimicrobial and phytochemical screening of Icacina trichantha. Am. J. Biomed. Life Sci. 1, 37-40.

Shikora, S.A., 2002. Nutritional considerations in the intensive care unit: Science, rationale and practice. Kendall/Hunt, Dubuque, lowa, US.

Teye, G.A., Coffie, M. \& Teye, M., 2011. Effects of raw false yam (Icacina oliviformis) seed meal in broiler rations on carcass yield and eating qualities of the meat. J. Anim. Sci. Adv. 1, 79-84.

Umoh, E.O. \& Iwe, M.O., 2014. Effects of processing on the nutrient composition of false yam (Icacina trichantha) flour. Nig. Food J. 32, 1-7.

Van Soest, P.J., Robertson, J.B. \& Lewis, B.A., 1991. Methods for dietary fiber, neutral detergent fiber, and nonstarch polysaccharides in relation to animal nutrition. J. Dairy Sci. 74, 3583-97. doi:10.3168/jds.S0022-0302(91)78551-2

VDLUFA (Verband Deutscher Landwirtschafts- und Forschungsanstalten), 2006. Chemical analysis of animal feed [Die chemische Untersuchung von Futtermitteln], Methodenbuch, Band III - Futtermittel. VDLUFA-Verlag, Darmstadt, Germany.

Zhao, M., Onakpa, M.M., Santarsiero, B.D., Chen, W.L., Szymulanska-Ramamurthy, K.M., Swanson, S.M., Burdette, J.E. \& Che, C.T., 2015. (9 BH)-pimaranes and derivatives from the tuber of Icacina trichantha. J. Nat. Prod. 78, 2731-2737. doi:10.1021/acs.jnatprod.5b00688. 